\section{Australian Journal of \\ Crop Science}

AJCS 13(08):1369-1374 (2019)

doi: 10.21475/ajcs.19.13.08.p1837

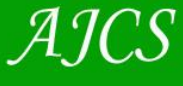

ISSN:1835-2707

\title{
Bioprospecting of endophytic bacteria (Bacillus spp.) from passionfruit (Passiflora edulis Sims $f$. flavicarpa) for plant growth promotion
}

\author{
Clayton dos Santos Silva ${ }^{1}$, Jockeliny Mayara Camara dos Santos ${ }^{3}$, João Manoel da Silva ${ }^{2}$, Felipe Alexandre \\ Tenório ${ }^{1}$, Erica Livea Ferreira Guedes-Celestino ${ }^{2}$, Crisea Cristina Nascimento de Cristo ${ }^{4}$, Matus da Silva \\ Nascimento ${ }^{1}$, Yamina Coentro Montaldo ${ }^{1}$, José Ubaldo Lima de Oliveira ${ }^{1}$, Tania Marta Carvalho dos \\ Santos $^{1}$
}

${ }^{1}$ Laboratory of Agricultural Microbiology, Centro de Ciências Agrárias, Universidade Federal de Alagoas, Br 104, Rio Largo, Alagoas, Brazil

${ }^{2}$ Rede Nordeste de Biotecnologia, Instituto de Quimica e Biotecnologia, Universidade Federal de Alagoas, Maceió, Alagoas, Brazil

${ }^{3}$ Laboratoty of Molecular Phytopathology, Centro de Ciências Agrárias, Universidade Federal de Alagoas, Br 104, Rio Largo, Alagoas, Brazil

${ }^{4}$ Instituto Federal de Educação de Alagoas, Campus Murici, Murici, Alagoas, Brazil

*Corresponding author: jm.agro@hotmail.com; joao.manoel@iqb.ufal.br

\section{Abstract}

Endophytic bacteria has been reported as plant growth promoters in various cultivated and uncultivated plants. Thus, the objective onf this study was to evaluate the potential of 21 endophytic bacterial isolated from leaves of passionfruit plants (Passiflora edulis Sims f. flavicarpa). In vitro antagonism, indole-3-acetic acid (IAA) production, gibberellins, cytokines and phosphate solubilization were also tested. In vitro antagonism was investigated using volatile metabolites detection by means of the overlapping dishes technique and direct confrontation. The production of IAA was evaluated by means of the colorimetric method with the absorbance reading of the optical density at O.D. $(550 \mathrm{~nm})$. The phosphate solubilization was measured in a qualitative method by reading the solubilization halo diameter and the quantitative evaluation in liquid medium and reading of O.D. (450 nm). All bacterial isolates were able to inhibit the growth of Phytophthora sp. in both methods with values ranging from $50 \%$ to $>90 \%$ inhibition (Skott-Knott, $\mathrm{p} \leq 0 \mathrm{0.05}$ ). All the tested endophytic bacteria were also able to produce plant hormones. The phosphate solubilization was more than mean of the liquid medium. Thus, the studied endophytic bacterial isolates are suggested as potential plant growth promoters.

Keywords: Phosphate solubilization, indole-3-acetic acid, volatile metabolites, Bacillus, giberelins, cytokines, biological control. Abbreviations: IAA_indole-3-acetic acid; OD_optical density; PDA_Potato Dextrose Agar; MGI\%_Mycelial Growth Inhibition; TSB_Triptone Soy Both; CFU_Colonies Forming Units; NBRIP_National Botanical Research Institute's Phosphate Growth Medium; rpm_rotarion per minute; ANOVA_Analysis of Variance.

\section{Introduction}

Agriculture is an activity that requires constant development and increase for the purpose of improving productivity to reduce the use of agrochemicals, chemical fertilizers and other products that are likely to degrade the environment or even reduce costs with the use of inputs. Thus, studies have been developed using microorganisms with capability of promoting plant growth such as endophytic bacteria.

Plant-growth-promoting endophytic bacteria have been reported as hosts in various agricultural crops and not cultivated plants, living in symbiosis with plants such as passionfruit (Passiflora edulis) (Santos et al., 2017), sugarcane (Saccharum officinarum L.) (Silva et al., 2015), (Manihot esculenta Crantz) (Leite et al., 2018), elephant grass (Pennisetum purpureum Schumach) (Li et al., 2016), among others. These studies strengthen the recognition of these as important agents in agriculture.

There are various applications for these microorganisms becuase they have various capabilities such as phosphorus solubilization (Otenio et al., 2015; Silva et al., 2018) and plant hormones production (Silva et al., 2015). Thus, they can be used as biotechnological resources to increase agricultural production.

Phosphorus $(P)$ is one of the macronutrients essential for the growth and development of plants due to its performance in biological processes, such as energy metabolism (Rocha et al., 2007). In most endophytic bacteria, the production of auxins, ethylene and cytokinins can increase water and nutrient uptake as well as the suppression of deleterious 
microorganisms which are responsible for promoting plant growth (Mariano et al., 2004).

Based on the above information, the objective of this study was to evaluate the potential of endophytic bacteria isolated from passionfruit ( $P$. edulis Sims f. flavicarpa) to promote plant growth through its functionalities.

\section{Results and Discussion}

\section{In vitro antagonism of Phytophthora sp.}

All the studied endophytic bacterial isolates were able to inhibit the mycelial growth of phytopathogen Phytophthora sp., as evidenced by in vitro antagonism tests. They exhibited more than $50 \%$ inhibition in the direct antagonism test and $80 \%$ in the presence of volatile metabolites (Table 1).

Bacteria of the Bacillus genera have been studied as antagonists of several etiological agents with agricultural importance (Silva et al., 2018). They were applied as extracellular filters and evidenced the existence of bioactive compounds. Therefore, they showed direct action to control Xantomonas campestres pv. Campestris. Silva et al. (2015) reported that endophytic bacteria of the Bacillus and Herbaspirillun genera are capable of controlling Curvularia inaequalis in direct application. Amorim and Melo (2002) observed inhibition of mycelial growth of $P$. parasitica and $P$. citrophthora uisng Bacillus subtilis $\mathrm{OG}$ and $B$. subtilis RC2 by $52 \%$ in in vitro tests. It is believed that the mechanisms of action of these bacteria in controlling phytopathogens is related to the production of toxic compounds responsible for the antagonistic action and siderophores, which causes competition for Fe (Amorim and Melo, 2002).

\section{Plant hormones production}

All isolates were able to synthesize IAA in the presence of $L$ Tryptophan. The highest amounts of IAA were observed at the end of 84 hours for the isolates BPE10 and BPE12 (11.24 and $10.93 \mu \mathrm{g} \cdot \mathrm{mL}^{-1}$, respectively) classified as medium producers (Table 2).

Previous studies have reported the production of this hormone, as described by Ashraf et al. (2011) who observed the potential of IAA production in rhizospheric bacteria associated with sugarcane, reaching maximum IAA production of $4.49 \mu \mathrm{g} \cdot \mathrm{mL}^{-1}$.

The IAA is considered as most important plant hormone among the auxins, functioning inside the cells as an important signal molecule responsible for cell expansion, division and differentiation, and regulation of genes. It improves the root architecture, stimulates root growth and number of root hairs and confers better nutrient and water absorption capacity to plants (Santoyo et al., 2016). Production of this hormone by microorganisms assists better development of plants, especially at unfavorable or stress conditions.

Out of all the studied isolates, $47.62 \%$ increase the weight of cotyledons. Cytokinins participate in the regulation of many plant processes, including cell division, foliar senescence, nutrient mobilization, apical dominance, apical meristem formation and activity, floral development, seed germination and gem dormancy breaking. In plants, cytokinins are synthesized in the roots, developing embryos, young leaves and fruits. They can also be synthesized by bacteria, insects and nematodes associated with plants (Table 2).

\section{Phosphate solubilization}

For in vitro phosphate solubilization, 11 out of the 21 endophytic bacterial isolates were able to produce solubilization halo at 15 days of incubation. Therefore, they were considered as potential solubilizers of phosphates. The BPE02 isolate was the most efficient in solubilizing phosphate differing from all other isolates studied ( $p \leq 0.05)$. In addition, the BPEO2 isolate presented exponential solubilization index, which is evidenced by observing the levels in each evaluation interval (Table 3).

Some isolates may be able to solubilize phosphate, but usually not under in vitro conditions in solid culture medium. The physical state of the culture medium and agitation may be factors influencing these results. According to Delvasto et al. (2006), the solid medium diffusion coefficient of the acids produced by the bacteria is different according to the acid produced and with culture medium. So, in liquid medium this problem does not exist, making the measurements more accurate. For this reason, all phosphate solubilization evaluations were quantitatively carried out in liquid NBRIP medium.

The bacterial isolates were the only statistically significant factors $(p \leq 0.05)$ in solubilization of inorganic phosphate in liquid medium NBRIP, where no effect for incubation time or interaction was detected. Table 4 shows the results of the quantitative analysis in $\mu \mathrm{g} \cdot \mathrm{mL}^{-1}$, where the solubilization of $\mathrm{P}$ remained constant in the evaluated period for all endophytes isolates. The average of soluble phosphorus at the end of the trial ranged from 29.87 to $178.68 \mu \mathrm{g} . \mathrm{mL}^{-1}$. The highest concentrations of solubilized $P$ were found in isolates BPE02 and BPE09 (178.68 and $128.49 \mu \mathrm{g} \cdot \mathrm{mL}^{-1}$, respectively).

Comparison of results between liquid medium (quantitative method) and solid (semi-quantitative) proved underestimation of the actual solubilization by the latter in some cases, whereas the isolates that did not solubilize in solid medium were able to fulfil in liquid medium. Similar results are described in previous studies by Nautiyal (1999) who observed that bacterial isolates with low solubilization capacity in solid medium were able to present significantly, when inoculated in liquid medium. Thus, the evaluation of phosphate solubilization is considered to be more effective when carried out in liquid culture medium.

\section{Materials and Methods}

\section{Bacterial isolates}

Twenty-one bacterial isolates from leaves of passionfruit plants were used. The isolates were identified and deposited in the collection of microorganisms of the Laboratory of Microbiology of the Federal University of Alagoas, belonging to the genus Bacillus. 
Table 1. In vitro mycelial growth inihibition index of Phytophtera sp. by endophytic bacteria isolated from passionfruit plants $(P$. edulis Sims f. flavicarpa) by means of direct confrontation and volatile metabolites.

\begin{tabular}{ccc}
\hline Bacterial isolate & Micelial growth inihibition (\%) & \\
\hline BPE01 & Direct antagonism & Volatile metabolites \\
BPE02 & $49.22 \mathrm{a}$ & $92.74 \mathrm{a}$ \\
BPE03 & $55.30 \mathrm{a}$ & $85.14 \mathrm{~b}$ \\
BPE04 & $49.77 \mathrm{a}$ & $85.62 \mathrm{~b}$ \\
BPE05 & $36.48 \mathrm{~b}$ & $89.85 \mathrm{a}$ \\
BPE06 & $57.14 \mathrm{a}$ & $91.96 \mathrm{a}$ \\
BPE07 & $51.88 \mathrm{a}$ & $86.85 \mathrm{~b}$ \\
BPE08 & $54.33 \mathrm{a}$ & $93.25 \mathrm{a}$ \\
BPE09 & $54.92 \mathrm{a}$ & $91.66 \mathrm{a}$ \\
BPE10 & $52.37 \mathrm{a}$ & $89.96 \mathrm{a}$ \\
BPE11 & $54.22 \mathrm{a}$ & $83.81 \mathrm{~b}$ \\
BPE12 & $44.48 \mathrm{~b}$ & $90.40 \mathrm{a}$ \\
BPE13 & $44.18 \mathrm{~b}$ & $86.18 \mathrm{~b}$ \\
BPE14 & $42.44 \mathrm{~b}$ & $90.48 \mathrm{a}$ \\
BPE15 & $51.11 \mathrm{a}$ & $84.85 \mathrm{~b}$ \\
BPE16 & $44.96 \mathrm{~b}$ & $87.48 \mathrm{~b}$ \\
BPE17 & $45.59 \mathrm{~b}$ & $89.11 \mathrm{a}$ \\
BPE18 & $44.70 \mathrm{~b}$ & $79.11 \mathrm{~b}$ \\
BPE19 & $57.48 \mathrm{a}$ & $93.37 \mathrm{a}$ \\
BPE20 & $56.29 \mathrm{a}$ & $92.96 \mathrm{a}$ \\
BPE21 & $49.35 \mathrm{a}$ & $86.81 \mathrm{~b}$
\end{tabular}

Table 2. Acid-3-indole acetic (IAA) production and giberelins and cytokins (showed by increase of cotyledons weight) by endophytic bacteria.

\begin{tabular}{lcc}
\hline Bacterial isolate & IAA production & Cotyledons weight $(\mathrm{mg})$ \\
\hline BPE01 & $2.22 \mathrm{~d}^{*}$ & $0.016 \mathrm{~b}$ \\
BPE02 & $5.10 \mathrm{c}$ & $0.019 \mathrm{a}$ \\
BPE03 & $4.82 \mathrm{c}$ & $0.022 \mathrm{a}$ \\
BPE04 & $5.08 \mathrm{c}$ & $0.017 \mathrm{~b}$ \\
BPE05 & $4.12 \mathrm{c}$ & $0.019 \mathrm{a}$ \\
BPE06 & $5.52 \mathrm{~d}$ & $0.021 \mathrm{a}$ \\
BPE07 & $7.30 \mathrm{~b}$ & $0.022 \mathrm{a}$ \\
BPE08 & $5.11 \mathrm{c}$ & $0.019 \mathrm{~b}$ \\
BPE09 & $7.16 \mathrm{~b}$ & $0.022 \mathrm{a}$ \\
BPE10 & $11.24 \mathrm{a}$ & $0.019 \mathrm{a}$ \\
BPE11 & $6.62 \mathrm{~b}$ & $0.020 \mathrm{a}$ \\
BPE12 & $10.93 \mathrm{a}$ & $0.016 \mathrm{~b}$ \\
BPE13 & $5.62 \mathrm{c}$ & $0.018 \mathrm{~b}$ \\
BPE14 & $8.54 \mathrm{~b}$ & $0.016 \mathrm{~b}$ \\
BPE15 & $1.83 \mathrm{~d}$ & $0.017 \mathrm{~b}$ \\
BPE16 & $1.83 \mathrm{~d}$ & $0.020 \mathrm{a}$ \\
BPE17 & $2.12 \mathrm{~d}$ & $0.018 \mathrm{~b}$ \\
BPE18 & $6.46 \mathrm{~b}$ & $0.018 \mathrm{~b}$ \\
BPE19 & $6.31 \mathrm{~b}$ & $0.019 \mathrm{a}$ \\
BPE20 & $1.86 \mathrm{~d}$ & $0.019 \mathrm{a}$ \\
BPE21 & $3.44 \mathrm{~d}$ & $0.018 \mathrm{~b}$ \\
\hline *Means followed by the same letter do not differ statistically (Skott-Knott $\mathrm{p} \leq 0.05)$.
\end{tabular}

Table 3. Efficiency of phosphate solubilization in NBRIP solid culture medium indicated by solubilization index (SI\%) after 5,10 and 15 days of incubation.

\begin{tabular}{lccc}
\hline \multirow{2}{*}{ Bacterial Isolates } & \multicolumn{3}{c}{ Incubation time (Days)* } \\
\cline { 2 - 4 } & 5 & 10 & 15 \\
\hline BPE02 & $2.99 \mathrm{aA}$ & $2.99 \mathrm{aA}$ & $3.11 \mathrm{aA}$ \\
BPE03 & $0.61 \mathrm{bA}$ & $0.61 \mathrm{cA}$ & $0.61 \mathrm{cA}$ \\
BPE06 & $1.59 \mathrm{bA}$ & $0.83 \mathrm{cA}$ & $1.28 \mathrm{cA}$ \\
BPE07 & $0.83 \mathrm{bA}$ & $1.94 \mathrm{bA}$ & $0.83 \mathrm{cA}$ \\
BPE08 & $1.77 \mathrm{bA}$ & $1.82 \mathrm{bA}$ & $1.89 \mathrm{bA}$ \\
BPE09 & $1.45 \mathrm{bA}$ & $1.16 \mathrm{cA}$ & $1.87 \mathrm{bA}$ \\
BPE12 & $1.16 \mathrm{bA}$ & $1.70 \mathrm{bA}$ & $1.16 \mathrm{cA}$ \\
BPE14 & $1.64 \mathrm{bA}$ & $0.98 \mathrm{cA}$ & $1.80 \mathrm{bA}$ \\
BPE19 & $1.06 \mathrm{bA}$ & $1.50 \mathrm{cA}$ & $0.98 \mathrm{cA}$ \\
BPE20 & $0.50 \mathrm{bB}$ & $1.16 \mathrm{cA}$ & $1.50 \mathrm{cA}$ \\
BPE21 & $1.18 \mathrm{bA}$ & $1.16 \mathrm{cA}$ \\
\hline
\end{tabular}

*Columns: lowercase letters. Lines: uppercase letters. Means followed by the same letter do not differ statistically from each other (Scott-Knott $\leq 0.05$ ). 
Table 4. Phosphate solubilization by endophytic bacteria after fifteen days of culture in liquid NBRIP media.

\begin{tabular}{lc}
\hline Bacterial isolate & P solubilized $\left(\mu \mathrm{g} \cdot \mathrm{mL}^{-1}\right)^{*}$ \\
\hline BPE01 & $59.68 \mathrm{f}$ \\
BPE02 & $178.68 \mathrm{a}$ \\
BPE03 & $66.24 \mathrm{e}$ \\
BPE04 & $63.72 \mathrm{e}$ \\
BPE05 & $45.10 \mathrm{~g}$ \\
BPE06 & $71.32 \mathrm{~d}$ \\
BPE07 & $50.55 \mathrm{~g}$ \\
BPE08 & $31.83 \mathrm{~h}$ \\
BPE09 & $128.49 \mathrm{~b}$ \\
BPE10 & $55.94 \mathrm{f}$ \\
BPE11 & $35.94 \mathrm{~h}$ \\
BPE12 & $75.40 \mathrm{~d}$ \\
BPE13 & $29.87 \mathrm{~h}$ \\
BPE14 & $76.90 \mathrm{~d}$ \\
BPE15 & $68.16 \mathrm{e}$ \\
BPE16 & $61.23 \mathrm{f}$ \\
BPE17 & $56.64 \mathrm{f}$ \\
BPE18 & $93.05 \mathrm{~d}$ \\
BPE19 & $58.80 \mathrm{f}$ \\
BPE20 & $82.40 \mathrm{~d}$ \\
BPE21 & $77.10 \mathrm{~d}$ \\
\hline Means followed by the same letter do not differ statistically (Scott-Knott $\leq 0.05)$.
\end{tabular}

\section{Antagonism assay}

The antagonism test was performed against Phytophthora sp., the etiological agent of various diseases in cultivated plants, well-known to cause rot base in the passionfruit. For in vitro antagonism test, the direct confrontation method was used on Petri dishes containing PDA (Potato Dextrose Agar) culture medium. In PDA medium, each bacterial isolate was paired with the Phytophthora sp., in $0.5 \mathrm{~cm}$ diameter disks containing medium and mycelium of the pathogen, with 1 distance $\mathrm{cm}$ from the edge of the Petri dish. At the oposite side, bacterial isolates were placed by multiple sowing technique. The control treatment consisted of the inoculation of Phytophthora sp. only. The dishes were incubated at room temperature for five days. The evaluations were carried out by measuring the diameter of the colony of the fungus, with the aid of a digital pachymeter. The mycelial growth inihibition (MGI\%) of Phytophthora sp. in relation to control was performed using the following formula:

$\% \mathrm{MGI}=\mathrm{C}-T / \mathrm{C} \times 100$

Where;

$\% \mathrm{MGI}=$ Percent of mycelial growth inihibition;

$\mathrm{C}=$ micelial growth os control;

$\mathrm{T}=$ mycelial growth of the treatment.

To evaluate the presence of volatile metabolites, PDA medium was poured into two Petri dishes covers, whereas the pathogen inoculated at the top and the antagonist at the bottom. To prevent loss of alleged volatile compounds, each plate was sealed with plastic wrap and placed for incubation at room temperature for five days.

\section{Plant hormones production}

The evaluation of the indole-3-acetic acid (IAA) production was carried out by qualitative and quantitative colorimetric methods. Test tubes with $10 \mathrm{~mL}$ of Triptone Soy Both culture medium (TSB) (10\%) supplemented with $5 \mathrm{mM}$ L-tryptophan were inoculated in triplicate with $100 \mu \mathrm{L}$ of bacterial inoculum (108 CFU. $\mathrm{mL}^{-1}$ (O.D. $\left.550 \mathrm{~nm}=0.1\right)$ ). Cultures were conditioned at $28{ }^{\circ} \mathrm{C}$ in the dark under constant agitation (150 rpm) for 24 hours. Soon after, they were centrifuged at $10,000 \mathrm{rpm}$ for 10 minutes to obtain the supernatant.

The amount of IAA per $\mathrm{ml}$ of culture was estimated by mixing $750 \mu \mathrm{l}$ of the Salkowski reagent $\left(7.9\right.$ mol.L $^{-1}$ of $\mathrm{H}_{2} \mathrm{SO}_{4}$ and $12 \mathrm{~g} \mathrm{FeCl}_{3}$ ) with $750 \mu \mathrm{L}$ of the supernatant, incubated for 30 minutes in the dark, followed by reading the O.D. at 550 $\mathrm{nm}$ in a spectrophotometer (model SP-22). The positive result was demonstrated by the formation of the rose color. The IAA concentration in the culture medium (y) was determined by comparison with a standard curve, using commercial IAA, by the equation: $y=34.507 x^{2}+43.802 x+$ 0.843 , where $x$ equals the absorbance values obtained. Isolates were classified according to Hartmann et al. (1983), which sets the following parameters for the production of IAA: low production ( $\left.<1 \mu \mathrm{g} \cdot \mathrm{mL}^{-1}\right)$; average production (1-10 $\left.\mu \mathrm{g} \cdot \mathrm{mL}^{-1}\right)$; high production (11-50 $\left.\mu \mathrm{g} \cdot \mathrm{mL}^{-1}\right)$ and high production ( $\left.>51 \mu \mathrm{g} \cdot \mathrm{mL}^{-1}\right)$.

Determination of gibberellins and cytokinins were performed by the adapted bioassay, allowing detection of cytokinins and gibberellins simultaneously. Cucumber cotyledons and hypocotyls were placed in Petri dishes with filter paper sterile from the inoculum of each isolate with the ribs facing down along with $5 \mathrm{~mm}$ of hypocotyls. The inoculum consisted of $1 \mathrm{~mL}$ of each isolate. Sterilized nutrient broth was used for the control treatment. The treatments were incubated at room temperature under continuous light. After three days, the cotyledons and hypocotyls were dried with absorbent paper, weighed and measured on an analytical balance where the weight was compared to that of the control.

\section{Phosphate solubilization}

The phosphate solubilization was carried out in two methods, one qualitative and one quantitative. For the qualitative evaluation, the isolates were evaluated in solid 
NBRIP medium supplemented with 1.5\% agar (Nautiyal, 1999). Measurements were made on the $5^{\text {th }}, 10^{\text {th }}$ and $15^{\text {th }}$ day after inoculation, where the translucent halo formed by colonies.

The solubilization index (SI) was classified according to the obtained indices (SI less than 2 is equal to low solubilization; $\mathrm{SI}$ between 2 and 3 is equal to average solubilization; $\mathrm{SI}$ greater than 3 is equal to a high solubilization) (Silva Filho and Vidor, 2000).

Quantitative analysis of P-Ca solubilization was performed in test tubes containing $10 \mathrm{~mL}$ of NBRIP liquid medium and inoculated in triplicate with $100 \mu \mathrm{L}$ of bacterial inoculum (108 CFU. $\mathrm{mL}^{-1}$ (O.D. $550=0.1$ )). The control consisted of tubes with $10 \mathrm{~mL}$ of NBRIP medium without inoculum.

All tubes were incubated for 15 days at $28^{\circ} \mathrm{C}$ with shaking at $180 \mathrm{rpm}$. After the incubation time, $1000 \mu \mathrm{L}$ of each sample was transferred to $1.5 \mathrm{~mL}$ microtubes, which were centrifuged at $10,000 \mathrm{rpm}$ for 5 minutes. Then, to $145 \mu \mathrm{L}$ of each sample, $570 \mu \mathrm{L}$ of distilled water and $285 \mu \mathrm{L}$ of ammonium molybdate-vanadate reagent $(5 \%$ ammonium molybdate and $0.25 \%$ ammonium vanadate, $1: 1(\mathrm{v} / \mathrm{v}))$ were added.

To obtain the standard curve, a stock solution of $\mathrm{KH}_{2} \mathrm{PO}_{4}$ $(0.0875 \%) \quad\left(0.1 \mathrm{mg}\right.$ P. $\left.\mathrm{mL}^{-1}\right)$ was prepared, from which aliquots of $1 \mathrm{~mL}$ to $10 \mathrm{~mL}$ were mixed with $2.5 \mathrm{~mL}$ of the amonium molybdate-vanadate reagent for a final volume of $50 \mathrm{~mL}$. After 10 minutes of reagent addition, the samples were read in a spectrophotometer at $420 \mathrm{~nm}$. For the negative control in spectrophotometer (model UV-1601 PC, Shimadzu), the solution was used without inoculum, constituted of $145 \mu \mathrm{L}$ of the NBRIP medium, added of $570 \mu \mathrm{L}$ of distilled water and $285 \mu \mathrm{L}$ of the ammonium molybdatevanadate reagent.

The experiments were performed in triplicate and the positive result was evidenced by the formation of yellow coloration. The results obtained in absorbance (values of $x$ ) were converted to the concentration of $\mathrm{P}\left(\mu \mathrm{g} \cdot \mathrm{mL}^{-1}\right)(y)$ by the equation: $y=\left(0.3041 x^{2}+0.2566 x+0.0213\right)^{*} 1000$. The isolates were classified according to the following indices: Absence of solubilization (-); low solubilization $\left(<50 \mu \mathrm{g} \cdot \mathrm{mL}^{-1}\right)$; medium solubilization (50-100 $\left.\mu \mathrm{g} \cdot \mathrm{mL}^{-1}\right)$; high solubilization (101-500 $\left.\mu \mathrm{g} \cdot \mathrm{mL}^{-1}\right)$ and high solubilization (>501 $\left.\mu \mathrm{g} \cdot \mathrm{mL}^{-1}\right)$.

\section{Statistical analysis}

The experimental design of the antagonism and hormone production trials was a completely randomized design. The phosphate solubilization assays were delineated in fully causalized and arranged split-plots time design. The data collected were submitted to analysis of variance (ANOVA) using the software Sisvar (Ferreira, 2014).

\section{Conclusions}

Endophytic isolates of Bacillus retrieve from passion fruit plants are able to inhibit the mycelial growth of Phytophtora sp. acting as bio-controller of phytopathogens, producing plant hormones such as auxins (IAA), cytokinins and gibberellins and solubilize phosphate, which characterize them as plant growth promoters bacteria with applicability in agricultural production.

\section{Acknowledgment}

The authors thank the National Council for Scientific and Technological Development (CNPq) for the financial support

\section{References}

Amorim EPR, Melo IS (2002) Ação antagônica de rizobactérias contra Phytophthora parasitica e $P$. citrophthora e seu efeito no desenvolvimento de plântulas de citros. Rev Bras Frutic. 24(2):565-568.

Ashraf MA, Hasool F, Mirza MF (2011) Nitrogen fixation and indole acetic acid production potential of bacteria isolated from Rhizosphere of sugarcane (Saccharum officinarum L.). Adv Biol Res. 5(6):348-355.

Delvasto P, Valverde A, Ballester A, Igual JM, Muñoz JA, González F, Blázquez ML, Garcia C (2006) Characterization of brushite as a re-crystallization product formed during bacterial solubilization of hydroxyapatite in batch cultures. Soil Biol Biochem. 38(9):2645-2654.

Ferreira DF (2014) Sisvar: a Guide for its Bootstrap procedures in multiple comparisons. Ciênc Agrotec. 38(2):109-112.

Hartmann A, Singh M, Klingmuller W (1983) Isolation and characterization of Azospirillum mutants excreting high amounts of indole acetic acid. Can J Microbiol. 29(8):916923.

Leite MCBS, Pereira APA, Souza AJ, Andreote FD, Freire FJ, Kuklinsky-Sobral J (2018) Bioprospection and genetic diversity of endophytic bacteria associated with cassava plant. Rev Caatinga. 31(2):315-325.

Li X, Geng X, Xie R, Fu L, Jiang J, Gao L, Sun J (2016) The endophytic bacteria isolated from elephant grass (Pennisetum purpureum Schumach) promote plant growth and enhance salt tolerance of Hybrid Pennisetum. Biotechnol Biofuels. 9(190):1-12.

Mariano RLR, Silveira EB, Assis SMP, Gomes AMA, Nascimento ARP, Donato VMTS (2004) Importância de bactérias promotoras de crescimento e de biocontrole de doenças de plantas para uma agricultura sustentável. Anais Acad Pernamb Ciên Agron. 1:89-111.

Nautiyal CS (1999) An effcient microbiological growth medium for screening phosphate solubilizing microorganisms. FEMS Microbiol Letters. 170:265-270.

Otenio N, Lally RD, Kixanuka S, Lloyd A, Ryan D, Germaine KJ, Dowling DN (2015) Plant growth promotion induced by phosphate solubilizing endophytic Pseudomonas isolates. Front Microbiol. 6(7):1-9.

Rocha FR, Papini-Terzi FS, Nishiyama Junior MY, Vêncio RZN, Vicentini $R$, Duarte RDC, Rosa Junior VE, Vinagre $F$, Barsalobres C, Medeiros AH, Rodrigues FA, Ulian EC, Zingaretti SM, Galbiatti JA, Almeida RS, Figueira AVO, Hemerly AS, Silva Filho MC, Menossi M, Souza GM (2007) Signal transduction related responses to phytohormones and environmental challenges in sugarcane. BMC Genomics. 8(1):2007.

Santos MS, Orlandelli RC, Polonio JC, Ribeiro MAS, Serragiotto MH, Azevedo JL, Pamphile JA (2017) Endophytes isolated from passionfruit plants: molecular identification, chemical characterization and antibacterial activity of secondary metabolites. J Appl Pharm Sci. 7(4):038-043. 
Santoyo G, Hagelsieb GM, Orozco-Mosqueda MC, Glick BR (2016) Plant growth-promoting bacterial endophytes. Microbiol Res. 183:92-99.

Silva CS, Tenório FA, Silva JM, Guedes-Celestino EL, Araújo RGV, Lima JRB, Montaldo YC, Santos TMCS (2018) Solubilização de fosfatos inorgânicos por bactérias endofíticas isoladas de maracujá amarelo (Passiflora edulis Sims f. flavicarpa). Enc Reg Agroecol Nord. 1(1):e3634.

Silva JM, Santos TMC, Albuquerque LS, Montaldo YC, Oliveira JUL, Silva SGM, Nascimento MS, Teixeira RRO (2015) Potential of endophytic bactéria (Herbaspirillum spp. And
Bacillus spp.) to promote sugarcane growth. Aust J Crop Sci. 9(8):754-760.

Silva RS, Moutinho BL, Santos DR, Vasconcelo-Rodrigues IS, Talamini V, Fernandes MF, Miranda-Fernandes RP (2018) Using antagonistic soil bacteria and their cell-free filtrates to control the black rot pathogen Xanthomonas campestris pv campestris. J Phytopathol. 166:494:501.

Silva Filho GN, Vidor C (2000) Solubilização de Fosfato por Microrganismos na presença de fontes de carbono. Rev Bras Ciênc Solo. 24:311-319. 